University of Nebraska - Lincoln

DigitalCommons@University of Nebraska - Lincoln

Publications from USDA-ARS / UNL Faculty

U.S. Department of Agriculture: Agricultural

Research Service, Lincoln, Nebraska

November 1991

\title{
Maize hybrid response to tillage under irrigated and dryland conditions
}

Wallace Wilhelm

University of Nebraska-Lincoln, wwilhelm1@unl.edu

Mark Reed Hinze

Hinze Consulting, Kenesaw, Nebraska, U.S.A.

C. O. Gardner

University of Nebraska-Lincoln

Follow this and additional works at: https://digitalcommons.unl.edu/usdaarsfacpub

Part of the Agricultural Science Commons

Wilhelm, Wallace; Hinze, Mark Reed; and Gardner, C. O., "Maize hybrid response to tillage under irrigated and dryland conditions" (1991). Publications from USDA-ARS / UNL Faculty. 102.

https://digitalcommons.unl.edu/usdaarsfacpub/102

This Article is brought to you for free and open access by the U.S. Department of Agriculture: Agricultural Research Service, Lincoln, Nebraska at DigitalCommons@University of Nebraska - Lincoln. It has been accepted for inclusion in Publications from USDA-ARS / UNL Faculty by an authorized administrator of DigitalCommons@University of Nebraska - Lincoln. 


\title{
Maize hybrid response to tillage under irrigated and dryland conditions
}

\author{
W.W. Wilhelm ${ }^{\mathrm{a}}$, Mark Reed Hinze ${ }^{\mathrm{b}}$ and C.O. Gardner ${ }^{\mathrm{c}}$ \\ ${ }^{a}$ U.S. Department of Agriculture, Agricultural Research Service, University of Nebraska, Lincoln, \\ Nebraska 68583, U.S.A. \\ 'Hinze Consulting, Kenesaw, Nebraska 68956, U.S.A. \\ ${ }^{\circ}$ Department of Agronomy, University of Nebraska, Lincoln, Nebraska 68583, U.S.A.
}

(Accepted 11 April 1990)

\begin{abstract}
Wilhelm, W.W., Hinze, M.R. and Gardner, C.O., 1991. Maize hybrid response to tillage under irrigated and dryland conditions. Field Crops Res., 26: 57-66.

The popularity of reduced-tillage cropping systems has emphasized the need to determine if maize (Zea mays L.) developed under conventional tillage systems (moldboard plow, disk, and harrow) is readily adaptable to conservation production systems (greater than $30 \%$ residue cover after planting). Past research has indicated that crops grown under conservation production systems are subjected to cooler and wetter soil conditions than crops grown with conventional tillage practices. Information is needed to determine if a significant interaction exists between tillage and hybrid in maize. Field experiments were conducted in 1982 and 1983 near Lincoln, Nebraska, U.S.A., on an Abruptic Argiaquoll and in 1983 near Gothenburg, Nebraska, U.S.A., on a Typic Haplustoll under dryland and irrigated conditions, respectively, to evaluate the response of eight hybrids to several tillage practices. Tillage practices studied were moldboard plow, tandem disk, and no-tillage. Tillage practice had a significant effect on only plant emergence at Lincoln during 1983 and dry matter production at Lincoln in 1982 and Gothenburg in 1983. Hybrids differed in plant population at harvest, rate of phenological development, leaf area and dry matter production, and grain yield. A significant tillage $\times$ hybrid interaction was observed for dry-matter production at the tasseling stage at Lincoln during 1983; however, no significant interactions were observed for grain-yield among the hybrids and tillage systems investigated. Results indicate that for the adapted hybrids tested, relative grain-yield comparisons will be maintained with both conservation and conventional tillage practices.
\end{abstract}

\section{INTRODUCTION}

The increasing popularity of reduced tillage systems among producers has emphasized the need to determine if maize (Zea mays L.) hybrids developed using conventional tillage practices (moldboard plow, disk, and harrow) are

\footnotetext{
'Joint contribution from U.S. Department of Agriculture, Agricultural Research Service and Agricultural Research Division, University of Nebraska-Lincoln, NE, 68583. Published as Paper No. 8961 Journal Series, Agricultural Research Division.
} 
readily adaptable to conservation tillage systems. Conservation tillage systems are management strategies which reduce loss of soil and water relative to conventional tillage, through use of non-inversion tillage and retention of crop residues on the soil surface (Anonymous, 1982). Several studies have been conducted to define the response of maize to various tillage practices (Alessi and Power, 1971; Barber, 1971; Mock and Erbach, 1977; Wilhelm et al., 1987). Generally, this research has indicated variability in the response of maize to tillage practice because of differences in soil temperature and water content. Differences in soil water content may contribute to tillage-induced grain-yield increases (Miller and Shrader, 1976; Legg et al., 1979) or decreases (Griffith et al., Mock and Erbach, 1977). Increased yields from conservation tillage generally occurred in years with rainfall which is slightly below normal, whereas decreased yields occurred on poorly drained soils.

Studies cited above have investigated the response of only one hybrid to various tillage practices. However, from four recent investigations (Hallauer and Colvin, 1985; Anderson, 1986; Newhouse and Crosbie, 1986; Kaspar et al., 1987) which assessed the tillage $\times$ hybrid interaction, it has been suggested that no significant interactions exist for grain-yield in maize. Three of these studies were conducted in the central maize production area of the U.S.A. (Hallauer and Colvin, 1985; Newhouse and Crosbie, 1986; Kaspar et al., 1987 ) and one in the eastern U.S. (Anderson, 1986). In contrast, Brakke et al. (1983) reported a significant genotype (inbreds, lines, and hybrids) $\times$ cropping-system [combination of tillage (conventional, conservation tillage, or ecofallow) and water-management (irrigation or dryland) practices ] interaction for grain-yield of maize at several sites in the Central Great Plains. Carter and Barnett (1987) also reported a tillage $\times$ hybrid interaction for yield of maize grown in the northern U.S.A. The current study was initiated to determine if selected maize hybrids respond differently to tillage practices under both dryland and irrigated conditions.

\section{MATERIALS AND METHODS}

This research was conducted at two sites over two years. The first site, at the University of Nebraska Agronomy Research Farm near Lincoln, Nebraska, USA $\left(40^{\circ} 51^{\prime} \mathrm{N} 96^{\circ} 45^{\prime} \mathrm{W}\right)$, on a Butler silt loam (fine, montmorillonitic, mesic Abruptic Argiaquolls), was used in both years of the study, 1982 and 1983 . The second site, $16 \mathrm{~km}$ north of Gothenburg, Nebraska, $\left(40^{\circ} 56^{\prime} \mathrm{N}\right.$ $100^{\circ} 10^{\prime} \mathrm{W}$ ), on a Cozad silt loam (fine-silty, mixed, mesic Typic Haplustolls ), was used in 1983.

All three experiments were designed as randomized complete blocks (three blocks ) with a split-plot arrangement of treatments. Tillage treatments were randomly applied to whole plots within blocks, and hybrids randomly assigned to subplots within whole plots. The previous crop at both sites was 
maize. Treatments were applied to the same experimental units in both 1982 and 1983 at the Lincoln site.

Tillage treatments were plow (moldboard plow, disk, and plant), disk (tandem disk and plant), and no-tillage (plant). Plow and disk treatments were cultivated once at the six-leaf stage. The Lincoln site had been under notillage management since 1978, while the Gothenburg site had not been tilled since 1981. All tillage operations were performed during the spring and early summer of each growth-season. One additional tillage operation, furrowing, was required at Gothenburg for irrigation. This was done soon after cultivation. A Kinze' planter (plateless planter with double-disk openers and ' $V$ ' press wheels) was used in all experiments. At Lincoln, the row spacing was $760 \mathrm{~m} \mathrm{~m}$ and whole plots were 6.1 (eight rows) $\times 24.4 \mathrm{~m}$. At Gothenburg, the row spacing was $910 \mathrm{~mm}$ and whole plots were 11.0 ( 12 rows $) \times 24.4 \mathrm{~m}$. Subplots were four and six rows wide at Lincoln and Gothenburg, respectively, and $6.1 \mathrm{~m}$ long. Target plant populations were 3.70 and 7.18 plants $\mathrm{m}^{-2}$ at the dryland and irrigated sites of Lincoln and Gothenburg, respectively. Six border rows were planted to 'Asgrow RX90' between whole plots to minimize effect of adjacent tillage treatments.

Hybrids used in this study (Table 1 ) were selected to represent a range of genetic backgrounds as well as being adapted to conditions in the Central Plains. The hybrid B73 $\times$ Mol7 and its reciprocal, Mo $17 \times B 73$, were included to determine if selection of male and female lines was important in

\section{TABLE 1}

Sources and relative maturity of selected hybrids used to evaluate the tillage response in maize

\begin{tabular}{|c|c|c|}
\hline Hybrid & Source & $\begin{array}{l}\text { Relative } \\
\text { maturity } \\
\text { (days) }\end{array}$ \\
\hline Asgrow RX777 & Asgrow Seed Company, Des Moines, IA & 115 \\
\hline A632 $\times$ A 619 & Sokota Seed Company, Brookings, SD & 105 \\
\hline B73 $\times$ Mo 17 & & 115 \\
\hline $\mathrm{B} 73 \times \mathrm{N} 132$ & & 115 \\
\hline Mo17 $\times$ B73 & NC Hybrids, Lincoln, NE & 115 \\
\hline N7 A $\times$ Mol7 & & 112 \\
\hline $\mathrm{N} 28 \times \mathrm{B} 14 \mathrm{~A}$ & Hoegemeyer Hybrids, Hooper, NE & 115 \\
\hline Pioneer 3183 & $\begin{array}{l}\text { Pioneer Hi-Bred International, Des } \\
\text { Moines, IA }\end{array}$ & 121 \\
\hline
\end{tabular}

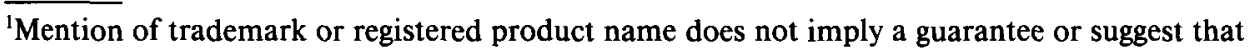
the product is superior to others that may have a similar function by the Agricultural Research Service or the University of Nebraska-Lincoln. 
hybrid response to tillage practice. Recent research has indicated that Mo17 $\times$ B73 is less cold tolerance than B73 $\times$ Mo17 (B. Doupnik, Univ. of Nebraska, personal communication, 1989). Colder soils, characteristic of reduced tillage, may influence the relative performance of these hybrids. In addition, B73 $\times$ Mo 17 represents a widely used standard hybrid for much of the U.S.A. maize production region. Asgrow RX777 was included because it has performed well in reduced tillage in west central Nebraska. The hybrid A632 $\times$ A619, although not generally used in this region, presents a hybrid with a different maturity range than the other selections. Hybrids B73 $\times$ N132 and $\mathrm{N} 7 \mathrm{~A} \times \mathrm{Mo} 17$ may show greater stress tolerance than the related B $73 \times$ Mo 17. Cultivars N28 $\times$ B14A has generally performed well in Nebraska yield trials. Pioneer 3183 was included because previous research (Alvarado, 1982 ) has indicated it performed well under a range of $\mathrm{N}$ application rates.

Herbicide applications were uniform in all experiments. Glyphosate was applied at $336 \mathrm{mg} \mathrm{m}^{-2}$ preplant to control vegetation existing prior to planting. Metolachlor and cyanazine were applied pre-emergence at 280 and 224 $\mathrm{mg} \mathrm{m}^{-2}$, respectively. Weed escapes were hoed by hand. Terbufos was applied at $627 \mathrm{mg} \mathrm{m}^{-1}$ of row at planting at Lincoln. At Gothenburg, phorate and carbofuran were applied at $627 \mathrm{mg} \mathrm{m}^{-1}$ of row at planting and at $756 \mathrm{mg} \mathrm{m}^{-2}$ aerially at cultivation, respectively.

Fertilizer was applied uniformly within each study. The Lincoln site received a preplant application of $7.8 \mathrm{~g} \mathrm{~N} \mathrm{~m}^{-2}$ as $\mathrm{NH}_{4} \mathrm{NO}_{3}$ both years of the experiment. The Gothenburg site received $22.5 \mathrm{~g} \mathrm{~N} \mathrm{~m}^{-2}$ as anhydrous $\mathrm{NH}_{3}$ at the 9-leaf stage. Irrigations of 87,170 , and $170 \mathrm{~mm}$ were applied on 23 July, 3 August, and 15 August 1983, respectively, at the Gothenburg site.

Air temperature and precipitation data were obtain from National Oceanographic and Atmospheric Administration records collected approximately $10 \mathrm{~km}$ from each of the sites. Deviations were calculated from Nebraska east central and southwest division normal air temperature and precipitation for the period 1951-1980 for the Lincoln and Gothenburg sites, respectively.

Plant population was measured four weeks after planting and four days prior to harvesting on each experimental unit. All populations were determined on 6.1-m segments of the center two rows.

Phenological development was determined weekly according to the scale described by Hanway (1963). The average stage of eight plants selected randomly from the center two rows of each experimental unit was recorded at each sampling date.

Dry-matter production was determined at stages $2.5,5.0$ and 10.0 (10-leaf, tasseling, and physiological maturity, respectively; Hanway, 1963). Eight plants were selected randomly for the 10-leaf sampling and four plants for both the tasseling and physiological-maturity sampling. Plants were selected from the outside two rows of each experimental unit. Area of mature green leaf blades was measured with a Lambda LI 3000 leaf-area meter. Leaf area 
index $(L)$ was calculated from these leaf-area data and plant population data collected four weeks after planting. Plant material was dried at $55^{\circ} \mathrm{C}$ and weighed to determine dry-matter production.

Grain-yield was determined by mechanically harvesting the center two rows of each experimental unit. Grain-yield is reported at $0.155 \mathrm{~kg} \mathrm{~kg}^{-1}$ water. Data were analyzed with analysis of variance and covariance techniques. Means were separated by Duncan's multiple range test and orthogonal contrasts (Steel and Torrie, 1980).

\section{RESULTS}

The two growth-seasons at the Lincoln site were very different. The 1982 season was much wetter $(+257 \mathrm{~mm})$ and slightly cooler $\left(-0.7^{\circ} \mathrm{C}\right)$ than normal. In contrast, 1983 had greater than normal precipitation during May and June, but precipitation was below normal for the remainder of the season. Mean air temperature for the growth season was only $0.4^{\circ} \mathrm{C}$ warmer than normal, but the months of July, August, and September were 2.3, 4.5, and $2.8^{\circ} \mathrm{C}$ above normal, respectively. High temperatures combined with a low rainfall resulted in less than ideal conditions in 1983 for the critical pollination and grain-fill periods in this dryland study. At the Gothenburg site, air temperatures were below normal while seasonal total precipitation was near normal. However, precipitation during August, September, and October was below normal.

Plant population at the three-leaf stage (four weeks after planting) did not differ among treatments for Lincoln-1982 (Table 2A) nor Gothenburg-1983 (Table 2C). Mean plant populations were 3.49 and 6.98 plants $\mathrm{m}^{-2}$, respectively. However, at Lincoln-1983 (Table 2B), no-tillage had a significantly lower population (2.63 plants $\mathrm{m}^{-2}$ ) than the disk (3.64 plant $\mathrm{m}^{-2}$ ) or plow (3.13 plant $\mathrm{m}^{-2}$ ) treatments. Carter and Barnett (1987) also found no-tillage reduced emergence more than conventional tillage (plow), with as much as $26 \%$ difference between numbers of seeds planted and the number of plants emerged in no-tillage. Kaspar et al. (1987) reported reduced plant populations at harvest with no-tillage compared to tilled treatments in one year of a two-year study. Although differences in population were found during one site-year in this study, the tillage $\times$ hybrid interaction was not significant at any of the site-years, indicating that all hybrids were reacting similarly to the condition which caused the reduced population in no-tillage at Lincoln-1983 (Table 2B). Plant population may influence other plant responses measured in this study. Therefore, data were analyzed with population as a covariable.

Phenological development (data not shown) was not influenced by tillage or the tillage $\times$ hybrid interaction. However, A632 $\times$ A619 matured more rapidly than the other hybrids.

Leaf area index was similar for all tillage and tillage $\times$ hybrid treatment 
TABLE 2

Analysis of variance for several traits of maize affected by tillage and hybrid

\begin{tabular}{|c|c|c|c|c|c|c|c|}
\hline \multirow[t]{4}{*}{ Source } & \multirow[b]{4}{*}{ DF } & \multicolumn{6}{|c|}{ Mean squares } \\
\hline & & \multirow{3}{*}{$\begin{array}{l}\text { Population }^{\mathrm{a}} \\
\text { (plants } \\
\mathrm{m}^{-2} \text { ) }\end{array}$} & \multirow{3}{*}{$\begin{array}{l}\text { Leaf } \\
\text { area } \\
\text { index }\end{array}$} & \multicolumn{3}{|c|}{ Dry-matter production $\left(\mathrm{g} \mathrm{m}^{-2}\right)$} & \multirow{3}{*}{$\begin{array}{l}\text { Grain } \\
\text { yield } \\
\left(\mathrm{t} \mathrm{ha} \mathbf{a}^{-1}\right.\end{array}$} \\
\hline & & & & \multicolumn{3}{|c|}{ Developmental stage ${ }^{c}$} & \\
\hline & & & & 2.0 & 5.0 & 10.0 & \\
\hline \multicolumn{8}{|c|}{ A. Lincoln-1982 } \\
\hline Total & 71 & 0.092 & 0.09 & 500 & 13700 & 39600 & 0.70 \\
\hline Blocks & 2 & 0.058 & 0.18 & 1500 & 23900 & 23700 & 1.37 \\
\hline Tillage $(T)$ & 2 & 0.089 & 0.06 & 100 & 65700 & $143000^{* *}$ & 2.07 \\
\hline Error A & 4 & 0.064 & 0.27 & 1500 & 16500 & 8800 & 1.35 \\
\hline Hybrid $(H)$ & 7 & 0.095 & $0.31^{* *}$ & $500^{*}$ & $32200^{*}$ & $100900^{* *}$ & $1.92^{* * *}$ \\
\hline$T \times H$ & 14 & 0.100 & 0.03 & 300 & 7000 & 13300 & 0.18 \\
\hline Error $\mathbf{B}$ & 42 & 0.094 & 0.05 & 200 & 6300 & 12000 & 0.27 \\
\hline Mean & & 3.49 & 1.67 & 116 & 692 & 1382 & 6.50 \\
\hline $\mathrm{CV}(\%)$ & & 8.78 & 13.19 & 12.70 & 11.45 & 7.93 & 7.99 \\
\hline \multicolumn{8}{|c|}{ B. Lincoln-1983 } \\
\hline Total & 71 & 0.437 & 0.09 & 7600 & 14500 & 22500 & 0.36 \\
\hline Blocks & 2 & 2.790 & 0.93 & 15500 & 15000 & 20800 & 0.23 \\
\hline Tillage $(T)$ & 2 & $6.150^{*}$ & 0.13 & 16300 & 19500 & 300 & 0.35 \\
\hline Error A & 4 & 0.268 & 0.39 & 36100 & 32200 & 2200 & 0.60 \\
\hline Hybrid $(H)$ & 7 & 0.117 & 0.08 & 2100 & 8000 & 17200 & $0.84^{* * *}$ \\
\hline$T \times H$ & 14 & 0.219 & 0.03 & 2700 & 10000 & 18700 & 0.31 \\
\hline Error B & 42 & 0.186 & 0.03 & 1800 & 4800 & 12400 & 0.21 \\
\hline Mean & & 3.13 & 0.89 & 313 & 431 & 586 & 1.10 \\
\hline $\mathrm{CV}(\%)$ & & 13.75 & 21.05 & 13.74 & 16.01 & 19.00 & 41.45 \\
\hline \multicolumn{8}{|c|}{ C. Gothenburg-1983 } \\
\hline Total & 71 & 0.385 & 0.12 & 1500 & 65500 & 116600 & 1.46 \\
\hline Blocks & 2 & 0.966 & 0.66 & 1600 & 58100 & 1500 & 0.04 \\
\hline Tillage $(T)$ & 2 & 0.347 & 0.32 & 12200 & 198000 & $185600^{*}$ & 2.61 \\
\hline Error A & 4 & 0.263 & 0.26 & 4900 & 205100 & 35000 & 4.26 \\
\hline Hybrid $(H)$ & 7 & $1.220^{*}$ & $0.20^{*}$ & 100 & 45000 & $169700^{*}$ & 2.03 \\
\hline$T \times H$ & 14 & 0.285 & 0.06 & 900 & 29600 & 62300 & 1.29 \\
\hline Error B & 42 & 0.314 & 0.08 & 800 & 45300 & 75700 & 1.13 \\
\hline Mean & & 6.98 & 1.68 & 135 & 1089 & 1582 & 5.22 \\
\hline $\mathrm{CV}(\%)$ & & 8.03 & 17.22 & 21.16 & 19.55 & 17.40 & 20.32 \\
\hline
\end{tabular}

${ }^{\mathrm{a}} 4$ weeks after planting.

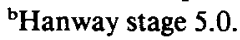

cHanway (1963).

${ }^{*, * *}$, indicate significance at the 0.05 and 0.01 levels according to the $F$-test.

combinations (Table 2) in all site-years, i.e. 1.67, 0.89 and 1.68, for Lincoln1982, Lincoln-1983, and Gothenburg-1983, respectively. At stage 5 (tasseling) hybrids differed in $L$ (Table 3 ). At Lincoln-1982, B73 $\times$ N132 and Pioneer 3183 had greater $L$ than the other hybrids. In all site-years, 


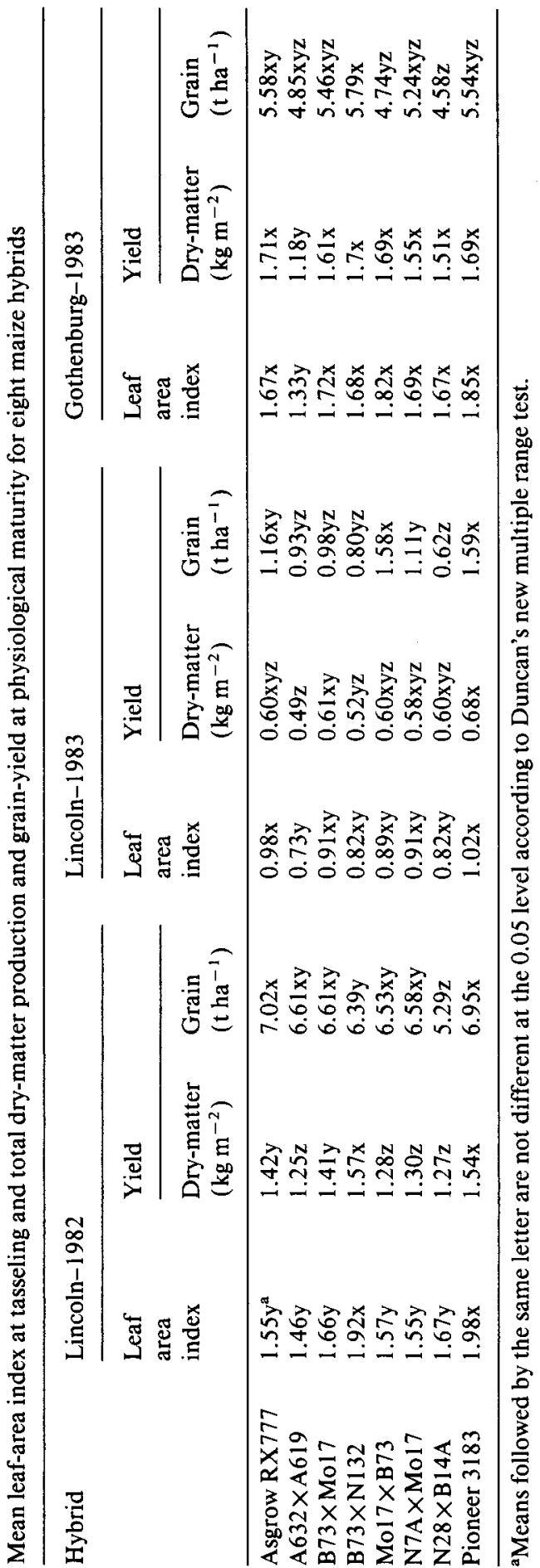


TABLE 4

Analysis of variance for grain-yield for site-year, tillage, and hybrid combinations

\begin{tabular}{|c|c|c|}
\hline Source & DF & Mean squares \\
\hline Total & 211 & 6.15 \\
\hline Site-year $(S)$ & 2 & $574.19^{* *}$ \\
\hline Blocks within $S$ & 6 & 1.27 \\
\hline Tillage (T) & 2 & 1.00 \\
\hline$T \times S$ & 4 & 3.45 \\
\hline Error A & 12 & 1.73 \\
\hline Hybrid $(H)$ & 7 & $3.62^{* *}$ \\
\hline$H \times S$ & 14 & $0.79^{*}$ \\
\hline$T \times H$ & 14 & 0.40 \\
\hline$T \times H \times S$ & 28 & 0.57 \\
\hline Error B & 122 & 0.43 \\
\hline Mean $\left(t \mathrm{ha}^{-1}\right)$ & \multirow{2}{*}{\multicolumn{2}{|c|}{$\begin{array}{r}4.27 \\
15.45\end{array}$}} \\
\hline $\mathrm{CV}(\%)$ & & \\
\hline
\end{tabular}

*,**, indicate significance at the 0.05 and 0.01 levels according to the $F$-test

A632 $\times$ A619 had the lowest $L$ at 1.46, 0.73 and 1.33, for Lincoln-1982, Lincoln-1983, and Gothenburg-1983, respectively.

Dry-matter production did not differ tillage or tillage $\times$ hybrid treatment combinations (Table 2) at the 10-leaf or tasseling stage at any site-year. At physiological maturity, corn grown on the various tillage treatments differed in dry-matter production in all experiments except Lincoln-1983. At Lincoln1982 , more dry-matter was produced for the disk treatment $\left(1.45 \mathrm{~kg} \mathrm{~m}^{-2}\right)$ than for the plow treatment $\left(1.32 \mathrm{~kg} \mathrm{~m}^{-2}\right)$. At Gothenburg-1983, more drymatter was produced for the disk treatment $\left(1.66 \mathrm{~kg} \mathrm{~m}^{-2}\right)$ than for the notillage treatment $\left(1.45 \mathrm{~kg} \mathrm{~m}^{-2}\right)$. Hybrids differed in dry-matter production at all sampling times during the very desirable 1982 growth-season, but during the very stressful year (Lincoln-1983) no hybrid differences were found (Table 2). At Gothenburg-1983, hybrids differed in dry-matter production only at physiological maturity, when $\mathrm{A} 632 \times \mathrm{A} 619\left(1.18 \mathrm{~kg} \mathrm{~m}^{-2}\right)$ produced less than the other hybrids $\left(1.64 \mathrm{~kg} \mathrm{~m}^{-2}\right)$.

Grain-yield did not differ among tillage and tillage $\times$ hybrid treatment combinations (Table 2). Hybrids differed in grain-yield during both years at the Lincoln site (Table 3). Generally, N28 $\times$ B14A (5.29 and $0.62 \mathrm{tha}^{-1}$ in 1982 and 1983, respectively) produced less grain than the other hybrids ( 6.67 and $1.16 \mathrm{t} \mathrm{ha}^{-1}$ in 1982 and 1983 , respectively). The tillage $\times$ hybrid interaction was not significant.

\section{DISCUSSION}

The lack of tillage $\times$ hybrid interaction for grain-yield within and across environments (Table 4 ) indicated that the hybrids reacted similarly to conser- 
vation and conventional tillage practices under the stressful conditions of the Central Plains with and without irrigation. These results are consistent with the reports by Mock and Erbach (1977), Hallauer and Colvin (1985), Anderson (1986), and Newhouse and Crosbie (1986), but contradict results of Brakke et al. (1983) and Carter and Barnett (1987). The study by Brakke et al. (1983) was also conducted in the Central Plains, but tested the response of a very wide range of cultivars to cropping systems, combinations of tillage practice and water management (fallow or irrigation). These factors were confounded with location. In addition, the earlier study (Brakke et al., 1983) was conducted at sites with elevation greater than $1200 \mathrm{~m}$, while the current experiments were conducted at 420 and $760 \mathrm{~m}$ for Lincoln and Gothenburg, respectively. Higher elevations are generally associated with more intense solar radiation and cooler night temperatures. Differences associated with the experimental sites and those associated with treatment combination of the two studies may have contributed to the differing conclusions.

\section{CONCLUSION}

Results indicate that, for the maize hybrids tested, relative grain-yield comparisons will be maintained regardless whether the crop is produced under conservation or conventional tillage systems. This conclusion is in agreement with the findings of Hallauer and Colvin (1985), Anderson (1986), Newhouse and Crosbie (1986) and Kaspar et al. (1987). However, the significant hybrid $\times$ site-year interaction (Table 4 ) indicated that, although hybrids should perform similarly under various tillage practices, there is a need to select the appropriate hybrid for specific site-year combinations. The site-year characteristics include soil conditions, fertilizer practices, water management, weather, and their interactions. These factors appear to have a greater affect on relative performance of adapted maize hybrids than do changes in soil environment resulting from the use of different tillage practices.

\section{REFERENCES}

Alessi, J. and Power, J.F., 1971. Corn emergence in relation to soil temperature and seeding depth. Agron. J., 63: 717-719.

Alvarado, L., 1982. Nitrogen use in a corn-soybean rotation in eastern Nebraska. M.S. Thesis. Univ. of Nebraska, Lincoln.

Anderson, E.L., 1986. No-till effects on yield and plant density of maize hybrids. Agron. J., 78: 323-326.

Anonymous, 1982. Resource Conservation Glossary (third edition). Soil Conservation Society of America, Ankeny, Iowa, 193 pp.

Barber, S.A., 1971. Effect of tillage practice on corn root distribution and morphology. Agron. J., 63: 593-597. 
Brakke, J.P., Francis, C.A., Nelson, L.A. and Gardner, C.O., 1983. Genotype by cropping system interactions in maize grown in a short season environment. Crop Sci., 23: 868-870.

Carter, P.R. and Barnett, K.H., 1987. Corn-hybrid performance under conventional and notillage systems after thinning. Agron. J., 919-926.

Griffith, D.R., Mannering, J.V., Galloway, H.M., Parsons, S.D. and Richey, C.B., 1973. Effect of eight tillage-planting systems on soil temperature, percent stand, plant growth, and yield of corn on five Indiana soils. Agron. J., 65: 321-326.

Hallauer, A.R. and Colvin, T.S., 1985. Corn hybrids response to four methods of tillage. Agron. J., 77: $547-550$.

Hanway, J.J., 1963. Growth stages of corn (Zea mays L.). Agron. J., 55: 487-491.

Kaspar, T.C., Crosbie, T.M., Cruse, R.M., Erbach, D.C., Timmons, D.R. and Potter, K.N., 1987. Growth and productivity of four corn hybrids as affected by tillage. Agron. J., 79: 477-481.

Legg, J.O., Stanford, G. and Bennett, O.L., 1979. Utilization of labeled-N fertilizer by silage corn under conventional and no-till culture. Agron. J., 71: 1009-1015.

Miller, E.L. and Shrader, W.D., 1976. Moisture conservation potential with conservation tillage treatments in the thick loess area of western Iowa. Agron. J., 68: 374-378.

Mock, J.J. and Erbach, D.C., 1977. Influence of conservation-tillage environment on growth and productivity of corn. Agron. J., 69: 337-340.

Newhouse, K.E. and Crosbie, T.M., 1986. Interaction of maize hybrids with tillage systems. Agron. J., 78: 951-954.

Steel, R.G.D. and Torrie, J.H., 1980. Principles and Procedures of Statistics: A Biometrical Approach (2nd edition). McGraw-Hill, New York.

Wilhelm, W.W., Schepers, J.S., Mielke, L.N., Doran, J.W., Ellis, J.R. and Stroup, W.W., 1987. Dryland maize development and yield resulting from tillage and nitrogen fertilization practices. Soil Tillage Res., 10: 167-179. 